\title{
THE FORMATION OF ACCOUNTING EDUCATION IN RUSSIA
}

\author{
Alexander V. Kuznetsov \\ Kuban State University, Russia \\ Marina M. Gurskaya \\ Kuban State University, Russia \\ Mikhail I. Kuter \\ Kuban State University, Russia
}

\begin{abstract}
The purpose of the paper is to research into the characteristic features of the evolution of accounting education in Russia, to identify the main stages of this historical process and their time limits. The formation of accounting education is considered as a purposeful process being the integral part of the reforms of Peter the Great, and in which the tsar himself played a leading role. It is proved that the training was carried out mainly by means of practical study abroad and mentoring. The story of Ivan Thames, who taught accounting to the youth, as well as of Petr Rychkov, who became the author of the first Russian publication concerning accounting, is used as an illustration. The first cases of the use of the adopted in Russia accounting terminology are presented. The forms of accounting books, applied in the $18^{\text {th }}$ century, are given. The establishment of the first Russian commercial colleges is presented. The characteristic features of the manuals of accounting used in these establishments are discussed. The paper contains historical facts that can be of interest to those who are interested in the history of Russia.
\end{abstract}

Keywords: Accounting education in Russia, history of Russian accounting, commercial colleges in Russia, first Russian manuals of accounting

JEL code: A200, M410, N000

\section{Introduction}

There is no doubt that the level of qualification of an accountant depends on the quality of his education. Therefore, it is important that the innovations in the training system of experts in accounting and auditing do not contradict the existing traditions to understand which is possible only after a careful study of the history of accounting education. Only in this case the continuity of schools and trends can be maintained.

Taking this into account it is necessary to trace the development of the accounting training system. Thus, in our view, it is important not only to characterize the significant events, but to show the influence of personality on the process as well. It is also necessary to show special features of the textbooks used in first commercial colleges. This will provide a multifaceted idea of how the formation of accounting education in Russia took place.

\section{Review of prior literature}

The descriptions of historical aspects concerning accounting education in Russia are quite limited, and, as a rule, presented in Russian. The known works, that are written in English, are not numerous (see Sokolov and Sokolov, 2010; Sokolov, 2016; Kuter and Sokolov, 2012). The last publication is reprinted in Chinese. The works of the representatives of other countries, who touched upon the issue in relation to their countries, are listed in alphabetical order according to the names of the authors: Baker (2014), Carmona (2005), Degos (1998), Galassi and Mattessich (2004), Napier (1996), Previts and Merino (1979), Richard (2002), Walker (2008), Yamey et al. (1963). 
Anyone who wants to get an idea about the development of the accounting education in Russia is destined to face a shortage of information on the topic and the need to gather the scattered information literally bit by bit. Of course, there is a great number of publications on the history of the Russian education, both general and commercial, history of entrepreneurship. However, accounting training is covered quite poorly in them. Usually they contain only the mentioning that accounting was taught in this or that educational institution. Apart from that, the majority of works were written by scholars, who were masters of historiography analysis, but who did not have any training in the accounting field.

On the other hand, professional accountants, who wrote about the history of accounting, often avoided the subject of education. Likewise, some works have inaccuracies that could misinform readers. For example, for a long time the major reference book on the history of accounting in Russia was the book "Accounting in its Historical Development", in which a prominent theorist A. M. Galagan erroneously states that the book "The Key of Commerce" (1783) is a translation of a treatise by Jan Ympyn de Christoffels (Galagan, 1927, p. 73).

The paragraph "Commercial Education and Training of Accounting Experts" is included in the book of the Soviet researcher V. A. Mazdorov "The History of Accounting in the USSR" (Mazdorov, 1972), but it contains only a general, rather a short overview. Mazdorov followed in Galagan's footsteps, attributing to Jan Ympyn the authorship of "The Key of Commerce".

For nearly 20 years, a sort of guide on the history of accounting for the Russian people is the fundamental work of Professor Y. V. Sokolov "Accounting: from the Beginning to the Present Day" (Sokolov, 1996), which traces the evolution of accounting thought from the moment of its appearance to the present day. But the scale of the set task did not allow to concentrate only on accounting education. Thus, the topic of discussion is explored insufficiently in the existing literary sources, the data of which requires systematization, processing and updating.

\section{The origin of the Russian accounting education in the era of Peter the Great}

The introduction of Russia to double entry system took place in the $18^{\text {th }}$ century, when Tsar Peter I was able, in the words of the great Russian poet A. S. Pushkin "to cut a window to Europe". Undoubtedly, "cut" is the exact word that accurately shows how quickly and decisively the ruler acted. The desire to introduce in his state the order that existed in the West arose after his visit to European countries, before that his predecessors did not leave their countries. In 1697-1698 the Russian delegation took a trip abroad, it was known as "The Grand Embassy". Having a general idea of Europe and a look, as the distinguished historian V. Klyuchevsky said, into "the workshop of its civilization", Peter I realized that the West had something to learn from. Therefore, he vigorously tried to attract foreign specialists who would agree to work in Russia and share their experience. There was a special needed for competent managers who were able to launch manufacturing and organize accounting in accordance with the most advanced methods.

The activity of the Dutchman Johann Thames can serve as an example. There is not much information about his origin. It is believed that he was the son of the Dutch engraver Pavel Thames who was invited by Peter I during "The Grand Embassy". The foreigner Johann Thames took the Russian name Ivan Pavlovich and by the royal decree was appointed the manager of Moscow textile manufacturing. This enterprise was of strategic importance because Russia virtually was creating its own fleet from scratch and for the manufacture of ship sails in greater volume there was a need for cloth. In 1722 Thames together with the Russian merchants established another manufacture, not in the capital but in Yaroslavl, a big and developed city, situated nearly $300 \mathrm{~km}$ from Moscow. The enterprise was quite successful. It continues to function nowadays, its current name - Open Joint Stock Company Yaroslavl 
Works for Technical Fabrics "Red Perekop". The history of the enterprise goes back almost 300 years, which makes it one of the oldest not only in Russia but also throughout Europe.

Presenting the summary of Ivan Thames' biography and showing that his work as the manager was quite effective, let us demonstrate his role in the development of Russian education in the field of accounting. The contemporaries said that Ivan Thames was a great expert in commerce. He was well in with Peter, who ordered to send young people to the businessman to study accounting. Among Thames' students there was also an eight-year-old P. Rychkov, who later became a famous geographer and ethnographer, the first corresponding member of the Russian Academy of Sciences. The knowledge gained was particularly useful when in 1732 he was appointed to the Port Customs of St. Petersburg. The accountant of this establishment was a foreigner and, correspondingly, kept books in German. Rychkov was his assistant and translator. Two years later, he was sent as an accountant on a government expedition for the development of the territories belonging to Orenburg region at present. Rychkov's biography shows that he accumulated extensive experience in accounting and, of course, was aware of its importance and wanted to tell others about it.

When in 1755 the first Russian journal, called "Monthly Compositions designed for the Use and Entertainment", appeared, P. I. Rychkov started publishing in it a series of articles entitled "The Correspondence Between Two Friends on Commerce". In these, he insists on the need to "keep regular books and always have ready and correct accounts" and emphasizes the importance of proper accounting and usefulness of commerce. In this regard, he is considered to be the author of the first Russian journal publication on accounting.

So, the demonstrated example of Ivan Thames and his disciple Petr Rychkov proves that the main form of teaching accounting in the first half of the $18^{\text {th }}$ century was tutorship. Foreign work experience was also common practice. In Peter's decree issued in 1723 it was ordered "to send merchants' children to foreign lands in number not less than 15 people abroad at a time, to take them back when the training was over, and to send new people in their place, those who returned were ordered to teach here in Russia (because it was impossible to send everyone); for that reason, they should be taken from all the noble cities for the purpose of carrying out the procedure everywhere". Thus, the tsar saw it that all the major centers were provided by accountants, he was well aware of the role of accountants in economy development.

It was during the reign of Peter I traditional accounting terminology was gradually brought into common use. The biggest event in the history of the Russian accounting was considered to be the publication on the $5^{\text {th }}\left(16^{\text {th }}\right)$ of April, 1722 of "Admiralty and Shipyard Management Regulations" or, as it was also called, "the Admiralty Regulations". It presented a code of laws and regulations governing the activities of the Navy department. This document provided a form of special register, which is of special interest, as the terms "debit" and "credit" were introduced in it. As they were new then for Russian users, the explanation was given that on the debit side there were entered sums to be received, and on the credit side - those actually received. From the point of view of modern accounting that was the book of debts registration (Figure 1).

\begin{tabular}{|c|c|c|c|c|c|c|c|c|c|c|c|}
\hline \multicolumn{6}{|c|}{ Must be received, or debit. } & \multicolumn{6}{|c|}{ Received, or credit. } \\
\hline $\begin{array}{l}\text { Months, } \\
\text { figures }\end{array}$ & $\begin{array}{c}\text { No. } \\
\text { on decrees }\end{array}$ & 1722 & 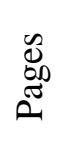 & $\frac{\frac{a}{0}}{0}$ & 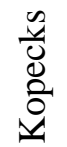 & $\begin{array}{l}\text { Months, } \\
\text { figures }\end{array}$ & $\begin{array}{c}\text { No. } \\
\text { on decrees }\end{array}$ & 1722 & 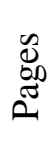 & $\begin{array}{l}\frac{a}{0} \\
\frac{0}{0} \\
\simeq\end{array}$ & 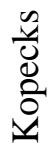 \\
\hline
\end{tabular}

Figure 1. The form of the book for the calculation of the Admiralty with contractors 
In addition, the Admiralty Regulations used the term "bukhgalter", which to this day in Russia represents experts in accounting. It is believed that it comes from the German word "buchhalter", which completely corresponds to "bookkeeper" in English. Professor Y. V. Sokolov suggested that the origin of this word is associated with the Swedish name "bokhallare". This version also has the right to life as during the establishment of the system of public administration it was the Swedish model that was used.

A personal decree "On the appointment of officials in the provinces, according to the Swedish territorial governance; on giving them instructions and on introducing new governance in St. Petersburg province since July 1" dates from 1718. In the assignment of officials in order to explain the meaning of the new term, the accountant was assigned to collection supervisor. In St. Petersburg, the new order was established in the second half of 1719 , and in other provinces - since 1720. To be precise, this decree appeared on November 26 according to Julian calendar, and, accordingly, on December 7 according to Gregorian calendar. Therefore, now December 7 is a professional holiday - Accountant's Day in Russia.

The position of an accountant in the chain of authority was fixed on January 24 (February 4) in 1722 in the "Table of Ranks for all Military, Civil and Courtier Ranks" - the law on the order of the civil service in the Russian Empire. It introduced the position of "bookkeeper at collegiums" which belonged to the lowest fourteen class. On the same level as that of an accountant there was the station master that is the head of the post unit. Such placement indicates that an accountant was considered only as a simple registrar. But we should not assume that accountants were underestimated. Competent specialists were in great demand. In the project for the establishment of the Academy of Sciences Peter I personally wrote about the need "to find an Accountant, who would teach others their knowledge".

For a wide range of assistance to the merchants and patronage of trade in 1715 Peter I established a special government agency - the Collegium of Commerce. The spread of commercial knowledge was one its functions among other things. The appearance in 1747 of the Russianlanguage edition of the encyclopedia by Jacques Savary des Bruslons "The Universal Dictionary of Trade and Commerce" (Dictionnaire universel de commerce) was an important step in this direction. It was published under the title "The Extract of Savary's Lexicon of Commerce". The translation from French was performed by the secretary of the Academy of Sciences S. Volchkov. In 1748 he also translated the famous work "The Perfect Merchant" (Le Parfait Négociant) written by Jacques Savary, father of Jacques Savary des Bruslons. It was ordered to send copies of the book to the province and distribute among the merchants.

After the ascent to the throne of Catherine the Great, whose reign is traditionally associated with the beginning of the Russian Enlightenment, the activity concerning the popularization of knowledge, which included economic knowledge as well, became significantly more intense. The empress signed the decree that laid the foundation of the Imperial Free Economic Society, which actually was the first public organization in Russia. Over the years it released "Proceedings of the Imperial Free Economic Society", which can be considered as the first Russian periodical economic publication. However, with only one journal it was impossible to solve all the problems. The establishment of an educational institution, where commercial sciences would be taught, was desperately required.

\section{The emergence of the commercial school}

In the second half of the $17^{\text {th }}$ century the best minds of the time started organizing the education system. The plan of creating a free establishment for the representatives of all classes, where fundamentals of commercial science would be taught, was developed by the eminent Russian public figure V. V. Krestinin. His proposals were submitted for consideration to 
Catherine the Great and received her approval. But for the implementation of the project significant funds were required. Private capital came to the aid.

In 1772 P. A. Demidov, a representative of the famous dynasty of Russian industrialists, known for his charity work, granted an enormous sum of 205 thousand roubles for the establishment of the educational institution. Thus, with the participation of the president of the Imperial Academy of Arts I. Betsky, who already had the experience of establishing the Smolny Institute for Noble Maidens and the Imperial Orphanage in Moscow, Commercial College was founded. It was named as the tribute to the great benefactor Demidov. Among other subjects pupils learned foreign languages, business correspondence, arithmetic as well as accounting.

\section{The characteristic features of the first accounting textbooks}

Presumably, as a textbook they used a book called "The Key of Commerce, or Trade, that is the science of accounting, demonstrating keeping the books and using merchant accounts" the first manual on accounting in Russia. However, for more than 200 years it remained anonymous, it was only known what was written on the title page: "Printed at the expense of the printer and the bookseller Ch. F. Kleen in St. Petersburg under the Imperial Artillery Engineering Gentry Cadet Corps. 1783" (see Figure 2).
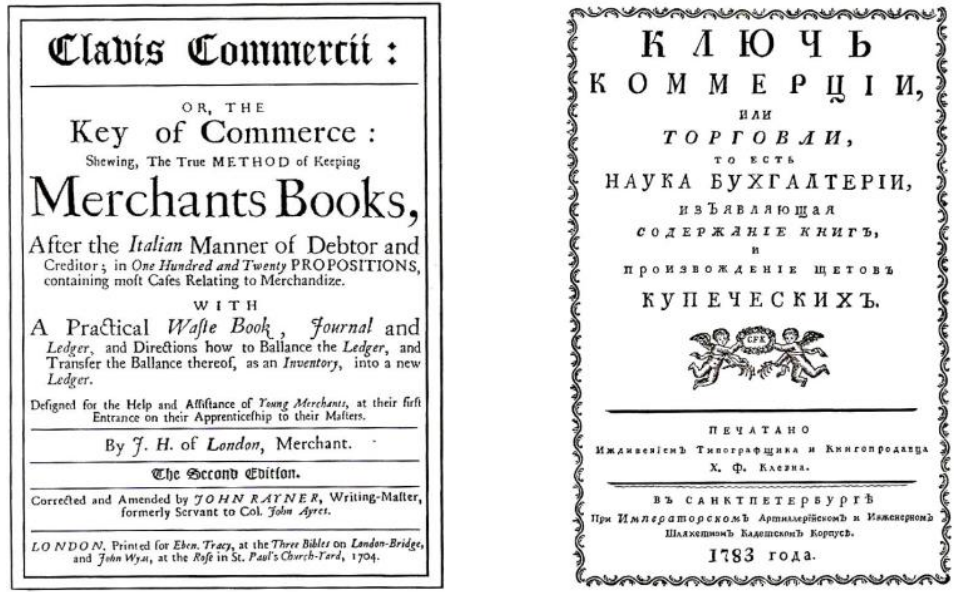

Figure 2. Cover Pages of the English and Russian editions of the book "The Key of Commerce"

In 1983 Soviet researcher V. D. Rak found that the book was a translation from the English language. Thanks to the search initiated by Professor Y. V. Sokolov, later it was possible to identify that the author of the original text "Clavis Commercii, or, The Key of Commerce ..." was the Englishman John Hawkins. In 2001 an authoritative Russian journal "Accounting" published an article (Sokolov and Bychkova, 2001) in which it was suggested why in the Russian edition the author was not indicated. According to it, Christian Friedrich Kleen "wanted, as it were, to allude to his authorship by putting down his name" (Sokolov and Bychkova, 2001, p. 71). A legitimate question arises whether this was so.

The main text of the book is preceded by "Introduction", which is not signed, but probably was written by the publisher, as it begins with the words: "By publishing this work, a new one of its kind in the Russian language, I respectably ask gentle readers to forgive those errors, which can occur, because it is published for the first time ..." (The Key of Commerce, 1783, p. 5). If at the beginning of the introduction there was a request to forgive mistakes found in the book, at the end it was offered to indicate them for correction in the new edition of it: "... I publish the book with the desire that the creator of it had, I consider it is necessary to inform me if someone finds any errors, then they will be corrected in the second edition..." (The Key 
of Commerce, 1783, p. 6). The last piece is critical because the "creator" appears in it, which is the author. It becomes clear that the author and the publisher are different people. Consequently, Kleen did not claim to be the creator of "The Key of Commerce". It is known that he rented a printing house in St. Petersburg Artillery and Engineering Cadet Corps from 1776, and was engaged in the sale of books. The name of the writer is not given in the book, it remains incognito: "The creator of this new instruction for his countrymen ... identified on the European model, which books should be necessary for an honest merchant, and briefly shows how to use them for someone's good" (The Key of Commerce, 1783, p. 6). The book "The Key of Commerce" could be considered new only for Russian people, and then here they are called compatriots of the writer. From this we can conclude that the person who wrote "Introduction" (presumably Ch. F. Kleen), sincerely believed the writer to be Russian (probably not Russian by nationality, but a foreigner who lived in Russia), who described the technology of accounting "according to the European model". This is acceptable if the publisher received not the original in English, but a finished translation. In that case, he could know nothing about the primary source. The given hypothesis to some extent justifies Ch. F. Kleen and serves as a response to those who would accuse him of dishonesty and a desire to hide the name of the author. The opinion that the publisher Ch. F. Kleen sought the glory of "Russian Luca Pacioli" was refuted as well. He worked for the public good and openly announced his motives (The Key of Commerce, 1783, p. 3): "Oh! How pleasant my hope is, if I do a service to the honorable public and publish this work for the first time in the Russian language, and that it will bring benefit Russian merchants in the Science of Accounting that until now was known just at Russian ports and then only to few".

The published book Ch. F. Kleen dedicated to P. A. Demidov, who as it has been said above, became the founder of the first commercial college, which in 1799 according to the imperial rescript was moved to St. Petersburg. In order that Moscow did not lose the status of the business education center, Emperor Alexander I issued a decree of March 12, 1804 concerning the establishment of the Moscow Imperial Commercial College, which was funded in the amount of 15 thousand roubles per year by the Moscow Merchant Society. Almost simultaneously with the Moscow Commercial College the Commercial Board was established. It is of interest to everyone who is keen on the history of accounting, as the creator was Karl-Johann von Arnold, who in the Russian style was called Karl Ivanovich. He is considered to be one of the founders of the Russian school of accounting.

Due to the active promotion of eminent merchants the Commercial Board, which was intended for the education of young men who wanted to join the merchant class, changed into the Moscow Practical Academy of Commercial Sciences. In accordance with the adopted Charter, the activities of the institution were aimed at "delivering the merchant class new means of educating their children according to their predestination, trying to bring them up good and honest citizens". Naturally, successful development of the disciplines required textbooks, in the time of the establishment of the Society of Commercial Knowledge, it was agreed that it would take measures for the publication of books, the subject of which was trade and accounting. Even during the existence of the Commercial Board K. J. Arnold had an intention to write educational books on accounting for the institution. He wanted his students who listened to the lectures in the basics of commercial sciences, which he read in German, a habitual language for himself, could read detailed explanations after the lectures in their native Russian language. The idea about writing a textbook got even more stronger after it became clear that such books practically do not exist in Russian, but there were significant obstacles, consisting in unacceptably high expenses needed for the publication of the book, as well as the absence of a specialist who would be sufficiently mastered both in German and Russian and also in commercial terminology in order to perform translation. 
In the end K. J. Arnold decided not to involve someone from outside and to find an appropriate interpreter at the Academy. His choice fell on two especially talented pupils: Vasily Kozlov and Ivan Nakhotkin. They agreed to help with the work on the Russian text and A. I. Pomerantsev, the teacher of literature and a longtime friend of Arnold, also joined the work and was the editor of the translation. As a result of joint efforts in 1809 "Teach Yourself Accounting" was released. This textbook is remarkable for containing the information of historical nature. For example, it said: "The first author who wrote about double-entry bookkeeping must be Luca Pacioli, an Italian, born in Borgo San Sepolcro, whose works, according to some people, were printed in Venice in 1494" (Arnold, 1809, p. XI).

Arnold believes that double entry has mathematical basis. He writes that when mathematics became a practice, it became clear that business transactions can be presented according to mathematical rules, and that every "affirmative" business must have its "negative" one. As proof the author gives several simplest algebraic equations. It is obvious that such an approach to the interpretation of double entry was very progressive for the time.

"Teach Yourself Accounting" defines accounting as "the science to conduct business relating to the merchant by recording in the book so accurately and in such order that you could observe them every hour" (Arnold, 1809, p. 1). It is noteworthy that accounting here is given the status of science. K. J. Arnold identifies in the property assets the following individual components: "...you can submit each article of commerce as a part of merchant's property or capital that was put into circulation for the owner's profit" (Arnold, 1809, p. V). We are talking about money, debts (money, that is indebted), real estate, that is about "all the things that can be sold, are of substantial price and provide benefit, which form part of the property, but each of which in this case may be, so to speak, special small property" (Arnold, 1809, p. VI). It lists the same conditions, which are required when accepting the asset to accounting in accordance with modern standards of financial statements: 1) the ability of an object to bring the organization economic benefits in the future as a result of its sale or other use; 2) the object has a sufficiently high (significant) value; 3 ) the ability to identify the object from other assets.

According to K. J. Arnold, the most important thing in the accounting is a reflection of the changes taking place with the objects (Arnold, 1809, p. VI): "The turnover of these parts of the property, being the occupation of the merchant, produces continuous change in its quantity or value, that is, the continuous increase or decrease in each part of the capital. Precise and accurate idea of this change is the only subject matter of Accounting". The author calls the double-entry such bookkeeping, when the changes of the two objects are recorded at the same time. The advantages of this system he connects with personification of accounts (Arnold, 1809, p. VI): "The benefit of double-entry bookkeeping is in the fact that every part of the property is represented in it as the very person whom we passed in the course of trade for a certain time a part of our business and from whom then demand a report". As it is known, the personification of accounts was widely used by Luca Pacioli.

We should also mention the described by Arnold classification of debts that are classified according to the degree of reliability on the right, doubtful and wrong (Arnold, 1809, p. 26): "To the first ones belong all those that are hoped to be paid at appropriate time; to the second - all those whose receipt is less likely; and to the third - all those that have no bare hope to be received". Such grouping of debts remains in Russia up until now (with the only difference that the right indebtedness is accepted to be called real, normal or usual, and the wrong one - bad). From the definition given in "Teach Yourself Accounting" it follows that the assessment of the reliability of debt is of purely subjective character, is based on personal assumptions of an accountant, that is, time criterion is not provided. 
Of course, the concept of accounting policy did not exist then, but the opportunity to select individual methods of accounting (for example, the option of assets valuation) did exist, Arnold himself confirms when he says that some traders estimated at the purchase price of the goods, and others - at the current one. Of the two estimates he prefers the second one and justifies this by saying that the merchant must always know the potential financial result: "I present the quantity of much or little purchased goods as if I have already sold them, and buy them again" (Arnold, 1809, p. 27). Evaluation of objects at the price of possible sale corresponds to the traditions of the static accounting, providing the possibility to find out whether the sale of existing assets will allow to pay debt obligations.

The information concerning inventory was recorded in the journal. In "Teach Yourself Accounting" there are examples of keeping it according to various systems, including an Italian one. Based on his own many years' experience, K. J. Arnold developed and successfully applied his own form of Memorial-Journal. From the common to us journal it differs only in that instead of the general content of business transaction, debtors and creditors are entered, accordingly the sums are put down twice. At the end of the month the columns of debits and credits are totalized, which must be equal to each other in the absence of mistakes. From the journal the sums are transferred to the Ledger, where accounts are located, and according to Arnold, they can be of two types: 1) personal; 2) impersonal. It is clear that personal accounts are opened for suppliers, customers and all other people with whom the merchant has business relationships. Impersonal accounts serve for accounting objects of property, primarily articles of commerce. The given grouping gives Arnold a chance to explain the reason for the appearance of accounts' personification: "Therefore, the merchant never puts down his own name in the books, but instead always uses impersonal accounts" (Arnold, 1809, p. 5). This is explained by an example: "...when I sell Jacob goods, I put instead of my name the word "goods" meaning that he, Jacob, owes goods, or for goods". Therefore, impersonal accounts replace the personal account of the merchant in the formation of the accounting records. The author also mentions the role of capital account in the opening of accounts (Arnold, 1809, p. 36): "If someone is involved in trading alone, he has an account called capital which is credited for Active (one's own) and debited for Passive (borrowed) property". To summarize, we can conclude that the main achievements of accounting science of that time found reflection in the book by K. J. Arnold. The acquaintance with "Teach Yourself Accounting" convinces that accounting in the Moscow Commercial Practical Academy was taught at a high level. At least all the necessary conditions were created for this. Despite the fact that the first Russian books on bookkeeping came to light nearly a three hundred years after the publication of the treatise "De Computis et Scripturis", they had a very significant impact on the development of education in the field of accounting in the country and are of interest to the present day.

The specific character of the procedure described in them is that the result of the sale is not displayed on a separate account that is used by modern accountants, but immediately on the financial account of each product. Luca Pacioli recommends to keep accounts in that way as well. Yet the main specific feature of the first textbooks is that the balance sheet equation linking assets, capital and liabilities is not applied for teaching bookkeeping, but a special universal rule is used for that purpose. That is how "the General Rule for all Accompts", expressed by J. Hawkins in Chapter XIX, "containing such Rules as are sufficient for the entering of all Parcels Debtor and Creditor, in all the Cases whatsoever that can happen in the whole course of a Merchant's Dealing, whether in Proper, Factorage, or Company Accompts, Domestick or Foreign", sounds: "All Things received, or the Receiver, must be charged, or made Debtor; and contrariwise, all Things delivered, or the Deliverer must be discharged or made Creditor" (Hawkins, 1704, p. 19). The analogous requirement is introduced by K. J. Arnold (Arnold, 1809, p. 23). 
Obviously, this rule is not observed in all the cases and it cannot explain some operations. Nevertheless, it can be very useful, especially at the basic stages of studying the theory of accounting. It may happen that the analysis of its shortcomings and their elimination will allow then to develop a new, improved rule that will noticeably facilitate students' understanding of double entry system. Undoubtedly, the study of ancient books should take its rightful place in the university accounting courses.

\section{Conclusion}

The given research allows to determine the following stages in the development of the Russian accounting education. At the first stage, which began after the Great Embassy of Peter I (1697-1698), the training occurred either when sending students abroad, or due to the assigning tutors to them. During this period, education was available to the minimal number of people. The second stage began with the opening in 1772 the first commercial school. Since that time, the number of students increased considerably as well as the quality of their training. And finally, the third stage should be dated from the appearance of accounting textbooks (1783). Education became of mass character, since those interested in accounting had the opportunity to learn it independently in the accounting books, i.e. to be occupied with selfeducation.

Looking back from the heights of the past centuries, we can say that with the course of time a lot has changed, but the overall system foundation, laid in the $18^{\text {th }}$ century, remains unshaken. According to the current federal law "On Education in the Russian Federation" the education should represent a single purposeful process of development and training, which is the benefit of public significance and is implemented for the benefit of individuals, families, society and the state, as well as a set of acquired knowledge, skills, value system, experience and competence of definite scope and complexity for the purpose of the intellectual, spiritual, moral, artistic, physical and (or) the professional development of a person, meeting his educational needs and interests. This is surprisingly in tune with the ideas that emerged during the reign of Peter the Great and the subsequent Enlightenment.

All the people, who are mentioned in one way or other in the paper, are united by the zeal for the future of the Russian education, the desire to contribute to the common good. The acquaintance with the history allows us to develop some sort of formula for success. First Russian commercial colleges were established by the merger of such main factors as the protection of the state, business sponsorship, rational project, experienced manager, who was able to implement the plan, talented teachers and no less than talentedly written textbooks.

Precisely textbooks and manuals of accounting on the pages of which the words of great thinkers and teachers are fixed, are of particular value, as they allow to judge the quality of teaching, and hence the effectiveness of accountants training. Readers of the 21 st century are eager to explore these books. It is proved by the huge wave of interest in the history of accounting, which arose in 2009 after the publication of the new translation of the treatise "De Computis et Scripturis" performed directly from the Old Italian language and provided with modern commentary by M. I. Kuter and Y. V. Sokolov. Unfortunately, the books "The Key of Commerce" and "Teach Yourself Accounting" have never been reprinted since the $19^{\text {th }}$ century. The detailed commentary explaining nuances has not also been compiled. It is hoped that this paper will help to draw attention of the global financial community to these wonderful books and the history of accounting education in Russia in whole. 


\section{Literature}

Arnold, K. J. (1809). Teach Yourself Accounting, written in German by the founder of Practical Academy of Commercial Sciences, titular counsellor Karl Johann Arnold and translated into Russian at this very Academy. Moscow. Free printing-house of Fyodor Lyuby.

Baker, C. R. (2014). A comparative analysis of the development of the auditing profession in the United Kingdom and France. Accounting History, vol. 19 (1-2), pp. 97-114.

Carmona, S. (2005). The History of Management Accounting in France, Italy, Portugal, and Spain. Instituto de Empresa Business School Working Paper No. WP05-30, available on-line at www.ssrn.com/abstract=1016360 (Accessed 15 Sep. 2016).

Degos, J. G. (1998). Histoire de la comptabilité. Paris: PUF.

Galagan, A. M. (1927). Accounting in its Historical Development. Moscow-Leningrad: State Publishing House. (in Russian)

Galassi, G., Mattessich, R. (2004). Italian Accounting Research in the First Half of the 20th Century, Review of Accounting and Finance, no. 3 (2), pp. 62-83.

Hawkins, J. (1704). Clavis commercii, or, The key of commerce: shewing, the true method of keeping merchant's books ... . London: Printed for Eben. Tracy and John Wyat.

Kuter, M. I., Sokolov, V. Y. (2012). Russia. In: Previts, G., Walton, P., Wolnizer, P. (eds) A Global History of Accounting, Financial reporting and public policy: Eurasia, The Middle East and Africa. Sidney: Emerald Group Publishing, pp. 75-106.

Mazdorov, V. A. (1972). The History of Accounting Development in the USSR (1917-1972). Moscow: Finansy. (In Russian)

Napier, C. J. (1996). Accounting and the absence of a business economics tradition in the United Kingdom. European Accounting Review, no. 5 (3), pp. 449-481.

Previts, G. J., Merino, B. D. (1979). A History of Accounting in America: An Historical Interpretation of the Cultural Significance of Accounting. New York: John Wiley and Sons.

Richard, J. (2002). History of fair value in accounting legislation of France and Germany from 1673 to 1914. Paper presented at European Accounting Association Annual Congress, Copenhagen, April.

Sokolov, V. (2016). Russian research in historiography of accounting. $14^{\text {th }}$ World Congress of Accounting Historians, Chieti-Pescara, Italy, 25-27 June 2016.

Available on-line at: www.wcah2016.org/papers/WCAH2016_paper_60.pdf (Accessed 17 Sep. 2016).

Sokolov, Y. V. (1996). Accounting: from the Beginning to the Present Day. Moscow: Audit, YuNITI.

Sokolov, Y. V., Bychkova, S. M. (2001). "Key of commerce" - the first book on double-entry bookkeeping in Russia. Accounting, no. 17, pp. 70-77.

Sokolov, Y., Sokolov, V. (2010). Accounting education in Russia: History and modernity. $2^{\text {nd }}$ Balkans and Middle East countries conference on auditing and accounting history (2 BMAC), September 15-18, vol. 1. 697-707.

The Key of Commerce, or Trade, that is the science of accounting... (1783). St. Petersburg: Publishing house under the Imperial Artillery Engineering Gentry Cadet Corps.

Walker, S. P. (2008). Innovation, convergence and argument without end in accounting histo- 
ry. Accounting, Auditing \& Accountability Journal, vol. 21. no. 2, pp. 296-322.

Yamey, B. S., Edey, H. C., Thomson, H. W. (1963). Accounting in England and Scotland: 1543-1800. Double Entry in Exposition and Practice. London: Sweet \& Maxwell. 